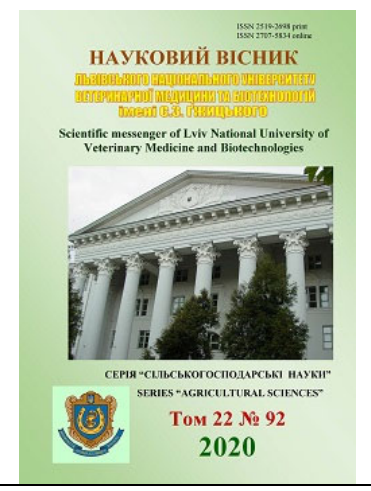

Науковий вісник Дьвівського національного університету ветеринарної медицини та біотехнологій імені С.3. Гжицького.

$$
\text { Серія: Сільськогосподарські науки }
$$

Scientific Messenger of Lviv National University of Veterinary Medicine and Biotechnologies. Series: Agricultural sciences doi: 10.32718/nvlvet-a9206

https://nvlvet.com.ua/index.php/agriculture

UDC 636.4:612.8

\title{
Influence of the microelement lactates on prooxidant-antioxidant homeostasis in boars
}

\author{
S. O. Usenko ${ }^{1}$, A. M. Shostya ${ }^{1}$, V. G. Stoyanovskyy ${ }^{2}$, G. O. Birta ${ }^{3}$, L. M. Kuzmenko ${ }^{1}$, O. I. Myronenko ${ }^{1}$ \\ ${ }^{1}$ Poltava State Agrarian Academy, Poltava, Ukraine \\ ${ }^{2}$ Stepan Gzhytskyi National University of Veterinary Medicin and Biotechnologies, Lviv, Ukraine \\ ${ }^{3}$ Poltava University of Economics and Trade, Poltava, Ukraine
}

\section{Article info}

Received 30.01.2020

Received in revised form 02.03 .2020

Accepted 03.03.2020

Poltava State Agrarian Academy, Skovorody Str., 1/3 Poltava, 36003, Ukraine.

Tel.: +38-0505211560

E-mail:sveta_usenko@ukr.net

Stepan Gzhytskyi National University of Veterinary Medicine and Biotechnologies Lviv, Pekarska Str., 50, Lviv, 79010, Ukraine.

Poltava University of Economics and Trade, Kovalia Str., 3, Poltava, 36000, Ukraine.

Usenko, S. O., Shostya, A. M., Stoyanovskyy, V. G., Birta, G. O., Kuzmenko, L. M., \& Myronenko, O. I. (2020). Influence of the microelement lactates on prooxidant-antioxidant homeostasis in boars. Scientific Messenger of Lviv National University of Veterinary Medicine and Biotechnologies. Series: Agricultural sciences, 22(92), 28-34. doi: 10.32718/nvlvet-a9206

The microelements, closely linked to enzymes, vitamins and hormones, cause the metabolic transformations to realize the genetic potential of the productivity in pigs. The use of chelate compounds of microelements as an alternative replacement of mineral salts allows to increase their conversion, to reduce the content in compound feeds, preventing environmental pollution. The purpose of the study was to determine the effect of microelement lactates on prooxidant-antioxidant homeostasis in boars. It was used the adult boars of the Large White breed in the study. The duration of the experiment was 120 days, including: preparatory one is 30 days, basic one is 60 days (feeding boars with zinc, selenium, copper and iron lactates) and the final one is 30 days. In the main period of the experiment, the diet of the animals in the control group remained unchanged, and the two experimental ones were with the addition of zinc, selenium, copper and iron. The level of biologically active components in the diet of the study groups was higher by $10 \%$ and $20 \%$ compared with the control group. In the obtained blood samples it has been determined the state of the prooxidant-antioxidant state. Feeding zinc, selenium, copper and iron lactates in the feed mixture for boars significantly changes the prooxidant-antioxidant state in the blood depending on the amount of micronutrients additionally fed. The addition of these biologically active substances by $10 \%$ above normal after 60 days of feeding helps to preserve the content of vitamins antioxidant action, restored glutathione, stimulates the functional activity of superoxide dismutase by $50 \%$ and catalase by $23.6 \%$ and is accompanied by a slight decrease processes of peroxidation decreasing the concentration of conjugates and TBAactive complexes. The addition of the microelement lactates to the feed mixture by $20 \%$ more than the norma for boars compared with the control group after 30 days of the consumption stimulates the processes of peroxidation, accompanied by intensive use of non-enzymatic - vitamin $A(P<0.05-0.01)$ and the activation of enzymatic antioxidants - superoxide dismutase $(P<0.05-0.01)$ and catalase, which lasts for 90 days.

Key words: blood, peroxidation, microelements, catalase, vitamins, TBA-active complexes.

\section{Вплив лактатів мікроелементів на прооксидантно-антиоксидантний гомеостаз у кнурів-плідників}

\author{
С. О. Усенко ${ }^{1}$, А. М. Шостя ${ }^{1}$, В. Г. Стояновський ${ }^{2}$, Г. О. Бірта ${ }^{3}$ Л. М. Кузьменко ${ }^{1}$, О. І. Мироненко ${ }^{1}$ \\ ${ }^{1}$ Полтавська державна аграрна академія, м. Полтава, Украӥна \\ ${ }^{2}$ Львівський національний університет ветеринарної медицини та біотехнологій імені С. 3. Гжиџького, \\ м. Львів, Україна \\ ${ }^{3}$ Полтавський університет економіки і торгівлі, м. Полтава, Украӥна
}


Мікроелементи, перебуваючи у тісному взаємозв'язку з ензимами, вітамінами та гормонами, обумовлюють метаболічні перетворення, забезпечуючи реалізацію генетичного потенціалу продуктивності у свиней. Використання хелатних сполук мікроелементів, як альтернативної заміни мінеральних солей дозволяє підвищити їх конверсію, знизити вміст у комбікормах $і$ запобігти забрудненню навколишнього середовища. Мета досліджень полягала у встановленні впливу лактатів мікроелементів на прооксидантно-антиоксидантний гомеостаз у крові кнурів-плідників. У дослідженні використано дорослих кнурів-плідників великої білоі породи. Тривалість експерименту становила 120 діб, у тому числі: підготовчий - 30, основний - 60 (згодовування лактатів цинку, селену, міді і заліза) та заключний - 30 діб. В основному періоді досліду раціон тварин контрольної групи залишався без змін, а двох дослідних - з добавкою лактатів циинку, селену, міді і заліза. Рівень біологічно активних компонентів у раціоні дослідних груп був вищим на $10 \%$ i 20\%, порівняно з контрольною групою. У отриманих зразках крові визначали стан прооксидантноантиоксидантного стану. Встановлено, щзо згодовування лактатів цинку, селену, міді $i$ заліза у складі кормосуміші кнурамплідникам істотно змінює прооксидантно-антиоксидантний стану у крові залежно від кількості додатково згодовуваних лактатів мікроелементів. Додавання ичих біологічно активних речовин на 10 \% понад норму після 60-ти діб згодовування сприяє збереженню вмісту вітамінів антиоксидантної дї̈, відновленого глутатіону, стимулює функціональну активність супероксиддисмутази на $50 \%$ і каталази - 23,6 \% та супроводжується незначним сповільненням процесів пероксидації- зниження концентраціі дієнових кон'югантів і ТБК-активних комплексів. Додаванням лактатів мікроелементів до кормосуміші на 20 \% більше від норми кнурам-плідникам порівняно з контрольною групою вже після 30-ти денного вживання стимулює процеси пероксидації, супроводжується інтенсивним використанням неензимних - вітаміну $A(P<0,05-0,01)$ та активацією ензимних антиоксидантів - супероксиддисмутази $(P<0,05-0,01)$ і каталази, щуо даний ефект триває протягом 90-ти діб.

Ключові слова: кров, пероксидація, мікроелементи, каталаза, вітаміни, ТБК-активні комплекси.

\section{Вступ}

Мікроелементи, перебуваючи у тісному взаємозв'язку з ензимами, вітамінами та гормонами, обумовлюють метаболічні перетворення, забезпечують реалізацію генетичного потенціалу продуктивності у сільськогосподарських тварин.

В умовах сьогодення використання хелатних сполук мікроелементів, як альтернативної заміни мінеральних солей дозволяє підвищити конверсію компонентів корму, знизити їх вміст у комбікормах, запобігти забрудненню навколишнього середовища (Borysevych et al., 2012; Vlizlo et al., 2018).

При організації повноцінної годівлі сільськогосподарських тварин особливу увагу приділяють задоволенню потреб у макро- та мікроелементах. Традиційно мікроелементи вводять у вигляді неорганічних солей, які засвоюються лише на 40-60\% через їх антогоністичну дію (Marchenkov \& Storozhuk, 2010). Нині, як альтернативну заміну для підвищення конверсії цих речовин у організмі, використовують їх хелатні комплекси (Bosanevich \& Lesik, 2018; Gorbatenko et al., 2018; Danchuk et al., 2018). Тому на сучасному етапі розвитку тваринництва виникає необхідність заміни неорганічних солей на органічні сполуки.

Серед мікроелементів, які визначають продуктивність тварин провідна роль належить цинку, селену, міді та залізу. Ці речовини регулюють ріст, розвиток та відтворення свиней (Quesnel et al., 2008; Peters et al., 2010; Wu et al., 2019). Більшість зазначених біологічних ефектів супроводжуються змінами прооксидантно-антиоксидантного гомеостазу через лабільність активностей антиоксидантних ензимів - супероксиддисмутази (активний центр $-\mathrm{Zn}, \mathrm{Cu}$ ), каталази (активний центр - Fe) та глутатіонпероксидази (активний центр - Se). Вміст даних мікроелементів у кормах часто визначає збереженість та біологічну доступність вітамінів та амінокслот для організму свиней (Sivertsen et al., 2007).

Доведено можливість покращення якості спермопродукції у кнурів-плідників в напрямі збільшення об'єму еякуляту, підвищення концентації, рухливості і виживаності сперміїв за рахунок додаткового згодо- вування мікроелементів (Nenkova et al., 2017; Pipan et al., 2017; Sutovsky et al., 2019). Такі особливості формування статевої функції супроводжуються глибокими змінами прооксидантно-антиоксидантного гомеостазу (Shostia et al., 2018). У зв'язку з цим представляються актуальними дослідження впливу окремих мікроелементів на формування даних гомеостатичних констант у кнурів-плідників, через їх значний вплив на процеси відтворення основного стада.

Мета досліджень полягала у встановленні впливу лактатів мікроелементів на проокидантноантиоксидантний гомеостаз у крові кнурів-плідників. Для досягнення поставленої мети виконувались такі завдання:

- досліджено вплив згодовуваних лактатів мікроелементів на інтенсивність процесів пероксидації у крові кнурів-плідників;

- з'ясовано вплив згодовуваних лактатів мікроелементів на формування системи антиоксидантного захисту в крові кнурів-плідників.

\section{Матеріал і методи досліджень}

Дослідження виконано в умовах лабораторії фізіології відтворення Інституту свинарства і агропромислового виробництва НААН та племінного заводу 3 розведення свиней великої білої породи ДП ДГ “Степне” IC і АПВ НААН. Для експерименту були відібрані 9 дорослих кнурів-плідників великої білої породи віком від 18 до 36 місяців. 3 яких сформовано три групи-аналоги тварин - I (контрольна) та II і III (дослідні), по три тварини у кожній.

Тривалість експерименту становила 120 діб, у тому числі: підготовчий - 30, основний - 60 (згодовування лактатів цинку, селену, міді і заліза) та заключний - 30 діб. В основному періоді досліду раціон тварин контрольної групи залишався без змін, а двох дослідних - $з$ добавкою лактатів цинку, селену, міді і заліза). Рівень біологічно активних компонентів у раціоні другої і третьої дослідних груп був вищим відповідно на 10 \% і 20 \% порівняно 3 контрольною групою.

Стан прооксидантно-антиоксидантного гомеостазу (ПАГ) у крові визначали за резистентністю еритроци- 
тів до пероксидного гемолізу (Kaidashev, 1996), активності ксантиноксидази (Shabunin, 2010), концентраціями дієнових кон'югатів - спектрофотометрично (Gavrilov \& Melkorudnaja, 1983) і ТБК-активних комплексів (альдегіди і кетони) - фотоелектроколориметрично (Kaidashev, 1996). Стан системи антиоксидантного захисту оцінювали за активностями супероксиддисмутази (Brusov, 1976) та каталази (Koroljuk et al., 1988) кількістю відновленого глутатіону (Shabunin, 2010), вітаміну А і вітаміну Е (Kovalenko et al., 2005), аскорбінової та дегідроаскорбінової кислот (Kaidashev, 1996).

Отриманий цифровий матеріал статистично опрацьовували за допомогою програми Statistica для WindowsXP. Після порівняння досліджуваних показників та їхніх міжгрупових різниць використовували tкритерій Ст'юдента, а результат вважали вірогідним після $\mathrm{P}<0,05$.

\section{Результати досліджень}

Отримані дані свідчать про те, що після згодовування лактатів мікроелементів у складі кормосуміші кнурам-плідникам III групи призводило до зниження резистентності еритроцитів до пероксидного гемолізу на $31 \%$ (30-а доба), 42,6 \% (60-а доба) і 19,0 \% (заключний період) порівняно із контролем (табл. 1). Можливо це обумовлено істотним збільшенням функціональної активності ксантиноксидази по завершенні другого і третього місяців експерименту відповідно на 15,4 і $16 \%$.

У крові кнурів-плідників, що додаткового на $10 \%$ більше споживали мікроелементи концентрація первинних продуктів пероксидного окиснення була нижчою після 60-денного вживання відносно контрольної групи на 25,2 \%, а по завершенню експерименту на $27,4 \%$.

\section{Таблиця 1}

Вплив лактатів мікроелементів на процеси пероксидного окиснення у крові кнурів-плідників, $\mathrm{M} \pm \mathrm{m}, \mathrm{n}=6$

\begin{tabular}{lccrrr}
\hline \multicolumn{1}{c}{ Показники } & \multirow{2}{*}{ Групи } & \multirow{2}{*}{ Підготовчий період } & \multicolumn{2}{c}{ Основний період } & 30-доба \\
\cline { 4 - 5 } Пероксидна резистент- & 1 & $9,47 \pm 1,88$ & $8,35 \pm 1,01$ & 90 -доба & \\
ність еритроцитів, \% & 2 & $8,22 \pm 1,63$ & $10,25 \pm 1,68$ & $9,08 \pm 0,81$ & $10,12 \pm 1,97$ \\
& 3 & $10,13 \pm 1,93$ & $10,85 \pm 1,69$ & $13,62 \pm 2,49$ & $12,03 \pm 1,75$ \\
Ксантиноксидаза, & 1 & $28,22 \pm 4,82$ & $30,16 \pm 5,27$ & $32,18 \pm 6,11$ & $30,95 \pm 4,02$ \\
мккат /сек·л & 2 & $24,35 \pm 4,03$ & $26,63 \pm 3,90$ & $36,12 \pm 4,35$ & $34,44 \pm 4,51$ \\
& 3 & $26,60 \pm 4,46$ & $28,43 \pm 4,72$ & $37,15 \pm 4,63$ & $35,86 \pm 5,03$ \\
Дієнові кон'югати, & 1 & $2,35 \pm 0,30$ & $2,08 \pm 0,41$ & $2,54 \pm 0,35$ & $2,88 \pm 0,58$ \\
мкмоль/л & 2 & $3,16 \pm 0,54$ & $2,25 \pm 0,33$ & $1,92 \pm 0,37$ & $2,09 \pm 0,23$ \\
& 3 & $1,92 \pm 0,23$ & $3,35 \pm 0,32$ & $3,88 \pm 0,51$ & $4,12 \pm 0,66$ \\
ТБК-активні сполуки, & 1 & $12,5 \pm 2,25$ & $15,17 \pm 2,24$ & $11,58 \pm 2,22$ & $12,92 \pm 2,38$ \\
мкмоль/л & 2 & $10,05 \pm 2,58$ & $12,92 \pm 2,38$ & $10,50 \pm 2,16$ & $11,73 \pm 2,25$ \\
ТБК-активні сполуки & 3 & $13,17 \pm 2,69$ & $18,60 \pm 2,17$ & $16,75 \pm 3,22$ & $15,83 \pm 3,11$ \\
після інкубування, & 1 & $15,08 \pm 2,83$ & $18,30 \pm 3,34$ & $14,83 \pm 2,26$ & $15,58 \pm 2,42$ \\
мкмоль/л & 2 & $14,55 \pm 2,43$ & $13,42 \pm 2,73$ & $12,17 \pm 2,24$ & $14,50 \pm 3,03$ \\
\hline
\end{tabular}

При цьому із збільшенням кількості згодовуваних мікроелементів (20\%) по закінченню першого і другого місяців основного періоду спостерігалось переважанням концентрації дієнових кон'югантів відповідно в 1,6 та 1,5 раза, а по завершенню експерименту в 1,4 раза відносно контрольної групи.

Найбільшу різницю за кількістю вторинних продуктів пероксидації відмічено по закінченню другого та третього місяців досліджень, де вміст цих речовин у тварин III групи був вищим відповідно на 43,9 \%, та $22,5 \%$, відносно контролю. Важливо відзначити, що після інкубування крові у прооксидантному буфері вміст ТБК-активних комплексів істотно зростав у зразках цієї групи протягом досліджуваних періодів на 21,5 \% (30-а доба), 42,5 \% (60-та доба) і 23,4 \% (заключний період). Додаткове згодовування лактатів мікроелементів у кількості 10\% понад норму викликало гальмування процесів пероксидації - зниження кількості ТБК-активних комплексів.

Рівень ензимних антиоксидантів у крові кнурівплідників протягом дослідного періоду коливався залежно дози згодовуваних лактатів мікроелементів (табл. 2). Так, активність супероксиддисмутази у цій тканині тварин II і III груп значно переважала відносно контролю, відповідно в 1,5 і 1,9 (Р < 0,01) раза на 60-ту добу основного періоду, а також в 1,3 $(\mathrm{P}<0,001)$ та $1,9(\mathrm{P}<0,01)$ раза по закінченню експерименту. Отримана динаміка даного ензиму вказує на провідну його роль у формуванні ПАГ та суттєвий вплив згодовуваних мікроелементів на процеси пероксидації, що підтверджується даними експериментів (Pipan et al., 2014).

Активність каталази у II і III груп була вищою за контрольну, переважаючи відповідно на 23,6 і 21,5 \% (30-та доба основного періоду). Однак після згодовування мінеральної добавки в кількості понад $10 \%$ протягом 60-ти діб встановлено зниження рівня даного ензиму на $12,0 \%$, а в умовах вживання понад $20 \%$ істотне зростання на $18,9 \%$, дана тенденція зберігалась до закінчення дослідження.

Згодовування лактатів мікроелементів кнурамплідникам протягом 60-ти діб сприяло інтенсивному використанню відновленого глутатіону в крові тварин II групи, де його вміст знижувався на 28,9 \%. Найбільш інтенсивне окиснення цієї речовини відмічено при вживанні комплексної добавки на 20 \% понад 
норму, яке супроводжувалось зниженням іiі концентрації відносно інтактних тварин на 21,9 (30-та доба) і 41,1 \% (60-та доба), а явище післядії тривало щонайменше місяць, однак міжгрупова різниця зменшува- лась, становлячи $18,6 \%$. Очевидно такий розподіл концентрацій глутатіону обумовлений його участю у відновленні аскорбінової кислоти.

\section{Таблиця 2}

Вплив лактатів мікроелементів на систему антиоксидантного захисту у крові кнурів-плідників, $\mathrm{M} \pm \mathrm{m}, \mathrm{n}=6$

\begin{tabular}{|c|c|c|c|c|c|}
\hline \multirow{2}{*}{ Показники } & \multirow{2}{*}{ Групи } & \multirow{2}{*}{ Підготовчий період } & \multicolumn{2}{|c|}{ Основний період } & \multirow{2}{*}{ Заключний період } \\
\hline & & & 30-доба & 60-доба & \\
\hline \multirow{3}{*}{$\begin{array}{l}\text { Супероксиддисмутаза, } \\
\text { у.о./мл }\end{array}$} & 1 & $0,425 \pm 0,083$ & $0,373 \pm 0,061$ & $0,328 \pm 0,044$ & $0,311 \pm 0,025$ \\
\hline & 2 & $0,355 \pm 0,058$ & $0,462 \pm 0,070$ & $0,508 \pm 0,097$ & $0,423 \pm 0,031^{* * *}$ \\
\hline & 3 & $0,458 \pm 0,053$ & $0,576 \pm 0,045$ & $0,608 \pm 0,047^{* *}$ & $0,578 \pm 0,056^{* *}$ \\
\hline \multirow{3}{*}{$\begin{array}{l}\text { Каталаза, } \\
\mathrm{H}_{2} \mathrm{O}_{2 / \text { хв./л }}\end{array}$} & 1 & $142,33 \pm 12,31$ & $144,25 \pm 14,92$ & $153,67 \pm 21,01$ & $160,83 \pm 24,03$ \\
\hline & 2 & $155,83 \pm 12,54$ & $175,38 \pm 25,21$ & $135,17 \pm 15,57$ & $133,21 \pm 21,11$ \\
\hline & 3 & $135,92 \pm 11,95$ & $178,37 \pm 22,71$ & $182,32 \pm 35,16$ & $164,35 \pm 16,11$ \\
\hline \multirow{3}{*}{$\begin{array}{l}\text { Відновлений глутатіон, } \\
\text { мкмоль/л }\end{array}$} & 1 & $0,353 \pm 0,041$ & $0,375 \pm 0,051$ & $0,433 \pm 0,079$ & $0,328 \pm 0,062$ \\
\hline & 2 & $0,467 \pm 0,051$ & $0,362 \pm 0,078$ & $0,308 \pm 0,067$ & $0,305 \pm 0,040$ \\
\hline & 3 & $0,375 \pm 0,073$ & $0,293 \pm 0,068$ & $0,255 \pm 0,039$ & $0,267 \pm 0,036$ \\
\hline \multirow{3}{*}{$\begin{array}{l}\text { Аскорбінова кислота, } \\
\text { ммоль/л }\end{array}$} & 1 & $22,36 \pm 3,05$ & $23,14 \pm 3,68$ & $20,67 \pm 3,11$ & $19,88 \pm 2,25$ \\
\hline & 2 & $27,32 \pm 2,93$ & $28,30 \pm 2,81$ & $30,16 \pm 3,89$ & $27,65 \pm 2,50$ \\
\hline & 3 & $23,93 \pm 4,48$ & $30,14 \pm 3,89$ & $23,65 \pm 4,74$ & $22,13 \pm 3,59$ \\
\hline \multirow{3}{*}{$\begin{array}{l}\text { Дегідроаскорбінова } \\
\text { кислота, ммоль/л }\end{array}$} & 1 & $22,75 \pm 3,76$ & $19,22 \pm 2,87$ & $23,52 \pm 3,22$ & $20,61 \pm 3,63$ \\
\hline & 2 & $23,42 \pm 3,36$ & $29,30 \pm 4,49$ & $25,32 \pm 3,52$ & $25,21 \pm 3,65$ \\
\hline & 3 & $20,93 \pm 3,84$ & $30,29 \pm 5,19$ & $29,21 \pm 2,39$ & $27,18 \pm 5,33$ \\
\hline \multirow{3}{*}{$\begin{array}{l}\text { Вітамін А, } \\
\text { ммоль/л }\end{array}$} & 1 & $1,52 \pm 0,19$ & $1,32 \pm 0,21$ & $1,68 \pm 0,17$ & $1,85 \pm 0,09$ \\
\hline & 2 & $1,72 \pm 0,23$ & $1,24 \pm 0,14$ & $1,58 \pm 0,24$ & $1,77 \pm 0,14$ \\
\hline & 3 & $1,82 \pm 0,21$ & $1,05 \pm 0,11$ & $0,88 \pm 0,09 * *$ & $1,22 \pm 0,15^{*}$ \\
\hline \multirow{3}{*}{$\begin{array}{l}\text { Вітамін Е, } \\
\text { ммоль/л }\end{array}$} & 1 & $12,75 \pm 2,57$ & $9,35 \pm 1,79$ & $11,52 \pm 1,66$ & $10,83 \pm 1,22$ \\
\hline & 2 & $10,05 \pm 1,59$ & $10,41 \pm 1,70$ & $14,63 \pm 2,26$ & $15,38 \pm 3,15$ \\
\hline & 3 & $13,93 \pm 2,86$ & $12,87 \pm 2,85$ & $13,47 \pm 2,17$ & $11,28 \pm 1,66$ \\
\hline
\end{tabular}

Кнури-плідники, що вживали лактати мікроелементів характеризувались вищим вмістом аскорбінової кислоти у крові. Так, під час вживання добавки у зразках цієї тканини II і III груп вміст даної кислоти переважав порівняно з контролем відповідно на 22,3 і $30,2 \%$ по закінченні першого, а також на 45,9 і 14,4 \% - другого місяців основного періоду, така закономірність зберігалась до закінчення експерименту. Важливо відзначити, що максимальною концентрацією аскорбінової кислоти характеризувались тварини, що споживали на 10 \% більшу кількість мікроелементів.

Вміст дегідроаскорбінової кислоти у тварин дослідних груп був вищим за контрольну, істотно переважаючи у 1,5 і 1,6 раза (30-та доба), 1,1 і 1,2 раза (60-та доба) та 1,2 і 1,3 раза (90-та доба експерименту).

Додавання мінеральної добавки до корму кнурівплідників суттєво впливало на вміст вітамінів антиоксидантної дії у крові. Найбільш виразні зміни спостерігались у зразках цієї тканини III групи, де кількість вітаміну А протягом дослідження знижувалась відносно контролю в 1,3 раза (30-ї доба), 1,9 раза (60-ї доба) $(\mathrm{P}<0,01)$ та 1,5 раза $(\mathrm{P}<0,05)$ протягом заключного періоду. Суттєвої різниці між концентраціями даного вітаміну у зразках I та II груп не спостерігалось.

У крові кнурів-плідників II та III груп концентрація вітаміну Е у крові була вищою порівняно із контролем. При цьому у отриманих зразках від тварин, що отримували на 10 \% вищу кількість мінеральної добавки, концентрація даного вітаміну була найвищою, переважаючи, відповідно до контрольної групи, на
26,8 (60-та доба основного періоду) та 41,7\% по закінченню експерименту.

\section{Обговорення}

Отримані результати досліджень свідчать про відчутний вплив лактатів цинку, міді, заліза і селену на формування ПАГ у крові кнурів-плідників, який полягає перш за все у зменшенні стійкості еритроцитів пероксидного гемолізу у тварин, що отримували максимальну кількість мікроелементів. Це очевидно обумовлено, підвищенням функціональної активності прооксидантного ензиму ксантиноксидази та прискореним накопиченням вмісту первинних і вторинних продуктів пероксидного окиснення. При цьому здатність до інактивації радикалів оксигену та пероксиду гідрогену залишалась на високому рівні - максимальні активності супероксиддисмутази та каталази. Особливої уваги заслуговує переважання вмісту аскорбінової і дегідроаскорбінової кислот, що очевидно пов'язано інтенсивним використання глутатіону та вітаміну E (Csala et al., 2001; Nardai et al., 2001). Зазначені зміни спостерігались вже після 30-ти денного вживання лактатів даних мікроелементів. Незначний дисбаланс ПАГ супроводжувався утворенням активних форм оксигену, які окислювали вітамін А і вітамін Е у мембранах еритроцитів, знижуючи їх стійкість до пероксидного гемолізу. Можливу пошкоджуючу дію активних форм оксигену на клітини ембріонів також відмічає M. Takahashi (Takahashi, 2012). 
Ефект від вживання кнурами-плідниками лактатів мікроелементів у кількості 10\% понад норму спостерігався вже на 60-у добу. Дія цих сполук проявлялась у суттєвому гальмуванні процесів пероксидації - мінімальна кількість дієнових кон'югантів та ТБКактивних сполук, назважаючи на переважання активності ксантиноксидази, супероксиддисмутази та каталази відносно інтактних тварин. Такі зміни відбувались на тлі максимальної концентрації аскорбінової кислоти, що очевидно супроводжувалось інтенсивним окисненням глутатіону, що збігається із твердженням про синегічний вплив останього на формування ПАГ за рахунок відновлення дегідроаскорбінової кислоти тіоловими білками (Bánhegyi et al., 2003; Fang et al., 2004). Зазначена кількість згодовуваних мікроелементів сприяла незначному використанню вітаміну А та дозволяла накопичувати вітамін Е по закінченню основного та заключного періодів експерименту. У цієї групи тварин мінеральна добавка, очевидно стимулювала утворення фізіологічно нормальних рівнів активних форм оксигену необхідно для проявлення реакцій імунітету (Valko et al., 2007) та передавання клітинних сигналів (Dröge, 2002; Nowicka-Bauer \& Nixon, 2020). У відповідь на дію кормового фактору (додаткової кількості двох валентних катіонів) організм тварин відповів підвищенням активності ензимних антиоксидантів у спермі. Встановлена особливість співпадає із твердженням про важливість контролю рівня активних форм оксигену у середовищах із розвитку гамет та доімплантаційних ембріонів (Ménézo \& Guérin, 2005). Це свідчить, про те, що мікроелементи поряд із антиоксидантами, що надходять із кормів кнурам-плідникам істотно змінюють процеси формування ПАГ, а їх ступінь впливу визначається згодовуваними дозами. Додавання органічних солей досліджуваних мікроелементів у корм у дозі $10 \%$ понад норму може бути використано для оптимізації процесів ПАГ у період максимальних фізіологічних навантажень в організмі цього виду тварин, особливо в період теплового стресу чи зміні режимів їх використання, коли інтенсифікуються процеси пероксидного окиснення (Shostia et al., 2017).

\section{Висновки}

Введення лактатів цинку, селену, міді і заліза у складі кормосуміші кнурам-плідникам істотно змінює стан ПАГ у крові залежно від кількості додатково згодовуваних лактатів мікроелементів. Додавання цих біологічно активних речовин на 10 \% понад норму після 60-ти діб згодовування сприяє збереженню вмісту вітамінів антиоксидантної дії, відновленого глутатіону, стимулює функціональну активність супероксиддисмутази на $50 \%$ і каталази - 23,6 \% та супроводжується незначним сповільненням процесів пероксидації - зниження концентрації дієнових кон'югантів i ТБК-активних комплексів. Додаванням лактатів мікроелементів до кормосуміші на $20 \%$ більше від норми кнурам-плідникам, порівняно 3 контрольною групою, вже після 30-ти денного вживання стимулює процеси пероксидації, супроводжується інтенсивним використанням неензимних - вітаміну А $(\mathrm{P}<0,05-$
0,01) та активацією ензимних антиоксидантів - супероксиддисмутази $(\mathrm{P}<0,05-0,01)$ і каталази, що триває протягом 90-ти діб.

\section{References}

Bánhegyi, G., Csala, M., Szarka, A., Varsányi, M., Benedetti, A., \& Mandl, J. (2003). Role of ascorbate in oxidative protein folding. Biofactors, 17(1-4), 3746. doi: 10.1002/biof.5520170105.

Borysevych, V. B. ta in. (2012). Nanomaterialy i nanotekhnolohii u veterynarnii medytsyni: navch.prakt. posibnyk. Kyiv: VD “Avitsena” (in Ukrainian).

Bosanevich, N. O., \& Lesik, Ya. V. (2018). Fiziologobiohimichni pokazniki organizmu ta produktivnist kroliv za diyi kobaltu citrate. Biologiya tvarin, 20(4), 89-89 (in Ukrainian).

Brusov, O. S., Gerasimov, A. M., \& Panchenko, L. F. (1976). Vlijanie prirodnyh ingibitorov radikal'nyh reakcij na avtookislenie adrenalina. Bjulleten' jeksperimental'noj biologii i mediciny, 1, 33-35 (in Russian).

Colagar, A. H., Karimi, F., \& Jorsaraei, S. G. (2013). Correlation of Sperm Parameters With Semen Lipid Peroxidation and Total Antioxidants Levels in Astheno- and Oligoasheno-Teratospermic Men Iran Red Crescent Med J., 15(9), 780-785. doi: 10.5812/ircmj.6409.

Csala, M., Szarka, A., Margittai, E., Mile, V., Kardon, T., Braun, L., Mandl, J., \& Bánhegyi, G. (2001). Role of vitamin $\mathrm{E}$ in ascorbate-dependent protein thiol oxidation in rat liver endoplasmic reticulum. Arch Biochem Biophys, 388(1), 55-59. doi: 10.3390/ijms10031346.

Danchuk, A. V., Karpovskij, V. I., Trokoz, V. A., \& Kaplunenko, V. G. (2018). Effektivnost primeneniya nanopreparata mikroelementov $\mathrm{Mg}, \mathrm{Zn}, \mathrm{Ge}$ i Ce dlya korekcii aktivnosti sistemy antioksidantnoj zashity $\mathrm{u}$ svinej raznyh tipov vysshejj nervnoj deyatelnosti. Perspektivy razvitiya svinovodstva stran SNG, 243247 (in Ukrainian).

Dröge, W. (2002). Free radicals in the physiological control of cell function. Physiol Rev., 82(1), 47-95. doi: 10.1152/physrev.00018.2001.

Fang,Y. Z., Yang, S., \& Wu, G. (2004). Free radical homeostasis. Sheng Li Ke Xue Jin Zhan., 35(3), 199204. https:/www.ncbi.nlm.nih.gov/pubmed/15469087.

Gavrilov, V. B., \& Melkorudnaja, M. I. (1983). Spektrofotometricheskoe opredelenie soderzhanija gidroperekisej lipidov v plazme krovi. Laboratornoe delo, 3, 33-36 (in Russian).

Gorbatenko, I. Yu., Gil, M. I., \& Zaharenko, M. O. (2018). Biologiya produktivnosti silskogospodarskih tvarin: pidruchnik. Mikolayiv:Vidavnichij dim "Gelvetika" (in Ukrainian).

Hartnett, P., Boyle, L., Younge, B. \& O'Driscoll, K. (2019). The Effect of Group Composition and Mineral Supplementation during Rearing on Measures of Cartilage Condition and Bone Mineral Density in Replacement Gilts. Animals (Basel), 9(9), 637. doi: 10.3390/ani9090637.

Iefimov, V. H. (2010). Osoblyvosti biokhimichnykh pokaznykiv krovi knurtsiv pislia transportuvannia ta $\mathrm{V}$ 
period adaptatsii za dii L-karnitynu ta E-selenu. Naukovo-tekhnichnyi biuleten Instytutu biolohii tvaryn i DNDKI vetpreparativ ta kormovykh dobavok, 11(2-3), 35-39 (in Ukrainian).

Jankowiak, D., Pilarczyk, R., Drozd, R., Pilarczyk, B., Tomza-Marciniak, A., Wysocka, G., Rząd, I., Drozd, A., \& Kuba, J. (2015). Activity of antioxidant enzymes in the liver of wild boars (Sus scrofa) from aselenium-deficient area depending on sex, age, and season of the year. Turkish Journal of Biology, 39(1), 129-138. doi: 10.3906/biy-1405-52.

Kaidashev, I. P. (1996). Posibnyk z eksperymentalnoklinichnykhdoslidzhen $\mathrm{z}$ biolohii ta medytsyny. Poltava, 123-128. (in Ukrainian)

Kołodziej, A., \& Jacyno, E. (2005). Effect of selenium and vitamin $\mathrm{E}$ supplementation on reproductive performance of young boars. Arch. Tierz., 48, 68-75. https://www.arch-anim-breed.net/48/68/2005/aab-4868-2005.pdf.

Koroljuk, M. A., Ivanova, L. I., Majorova, I. G., \& Tokarev, E. V. (1988). Metod opredelenija aktivnosti katalazy. Laboratornoe delo, 1, 16-19 (in Russian).

Kovalenko, V. F, Shostia, A. M., \& Usenko, S. O. (2004). Sposib pryskorenoho vyznachennia vmistu vitaminu C ta yoho izomeriv $\mathrm{u}$ spermi knuriv. pat. 67054A Ukraina: MPK A61V5/00.; zaiavl.13.06.2003 ; opubl. 15.06.2004.6. 16-19. (in Ukrainian).

Kovalenko, V. F., Shostia, A. M., \& Usenko, S. O. (2005). Metodyka vyznachennia vitaminiv A, E i zahalnoho kholesterynu $\mathrm{V}$ riznykh tkanynakh svynomatok plodiv. Suchasni metody v svynarstvi / za red. V.P. Rybalka. Poltava, 114-118 (in Ukrainian).

Linster, C. L. \& Van Schaftingen, E. (2007). Vitamin C. Biosynthesis, recycling and degradation in mammals, 274(1), 1-22. doi: 10.1111/j.1742-4658.2006.05607.x.

Mahan, D. C., \& Shields, R.G. Jr. (1998). Macro- and micromineral composition of pigs from birth to 145 kilograms of body weight. J Anim Sci., 76(2), 506512. doi: 10.2527/1998.762506x.

Marchenkov, F. S., \& Storozhuk, T. V. (2010). Helatni mikroelementi - vazhlivij komponent kombikormiv ta premiksiv. Zernovi produkti i kombikormi, 1, 37-38 (in Ukrainian).

Ménézo, Y., \& Guérin, P. (2005). Gamete and embryo protection against oxidative stress during medically assisted reproduction. Bull Acad Natl Med., 189(4), 715-726. https://www.ncbi.nlm.nih.gov/pubmed/ 16245687

Nardai, G., Braun, L., Csala, M., Mile, V., Csermely, P., Benedetti, A., Mandl, J., \& Banhegyi, G. (2001). Protein-disulfide isomerase- and protein thioldependent dehydroascorbate reduction and ascorbate accumulation in the lumen of the endoplasmic reticulum. J. Biol Chem., 276(12), 8825-8828. doi: $10.1074 /$ jbc.M010563200.

Nenkova, G., Petrov, L., \& Alexandrova, A. (2017). Role of Trace Elements for Oxidative Status and Quality of Human Sperm Balkan Med J., 34(4), 343-348. doi: 10.4274/balkanmedj.2016.0147.

Nowicka-Bauer, K., \& Nixon, B. (2020). Molecular Changes Induced by Oxidative Stress that Impair
Human Sperm. Motility Antioxidants (Basel), 9(2), 134. doi: 10.3390/antiox 9020134 .

Peters, J. C., Mahan, D. C., Wiseman, T. G., \& Fastinger, N. D. (2010). Effect of dietary organic and inorganic micromineral source and level on sow body, liver, colostrum, mature milk, and progeny mineral composition over six parities. Journal of Animal Science, 88, 626-637. doi: 10.2527/jas.2009-1782.

Pipan, M. Z., Mrkun, J., Strajn, B. J., Vrtač, K. P., Kos, J., Pišlar, A., \& Zrimšek, P. (2017). The influence of macro- and microelements in seminal plasma on diluted boar sperm quality. Acta Vet Scand., 59(1), 11. doi: 10.1186/s13028-017-0279-y.

Pipan, Z. M., Mrkun, J., Kosec, M., Nemec Svete, A., \& Zrimšek, P. (2014). Superoxide Dismutase: A Predicting Factor for Boar Semen Characteristics for Short-Term Preservation. Biomed Res Int., 2014, Article ID 105280. doi: 10.1155/2014/105280.

Quesnel, H., Renaudin, A., Le Floc'h, N., Jondreville, C., Père, M. C., Taylor-Pickard, J. A., \& Le Dividich, J. (2008). Effect of organic and inorganic selenium sources in sow diets on colostrum production and piglet response to a poor sanitary environment after weaning. Animal., 2(6), 859-866. doi: $10.1017 / \mathrm{S} 1751731108001869$.

Rokotianska, V. O. (2018) Vplyv nanoakvakhelativ na biolohichnu povnotsinnist spermiiv. Visnyk ahrarnoi nauky Prychornomoria. Seriia: Tvarynnytstvo, 3, 5661. doi: 10.31521/2313-092X/2018-3(99)-9 (in Ukrainian).

Shabunin, S. V. (2010) Metodicheskie polozhenija po izucheniju processov svobodnoradikal'nogo okislenija $\mathrm{v}$ sisteme antioksidantnoj zashhity organizma. Voronezh, 36-37 (in Russian).

Shostia, A. M., Rokotianska, V. O., Tsybenko, V. H., \& Sokyrko, M. P. (2017). Osoblyvosti protsesiv peroksydnoho okysnennia u spermi knuriv-plidnykiv zalezhno vid pory roku ta intensyvnosti yikh vykorystannia. Visnyk Dnipropetrovskoho derzhavnoho ahrarno-ekonomichnoho universytetu, 4, 34-38. http://nbuv.gov.ua/UJRN/vddau 201748 (in Ukrainian)

Shostia, A. M., Rokotianska, V. O., Tsybenko, V. H., Sokyrko, M. P., Hyria, V. M., Nevidnychyi, O. S., Kaplunenko, V. H., \& Pashchenko, A. H. (2018). Vplyv nanoakvakhelativ na yakist spermoproduktsii u knuriv-plidnykiv. Visnyk Sumskoho natsionalnoho ahrarnoho universytetu. Seriia: Tvarynnytstvo, 7(35), 156-160. http://dspace.pdaa.edu.ua:8080/handle/ 123456789/5224 (in Ukrainian).

Sivertsen, T., Vie, E., Bernhoft, A., \& Baustad, B. (2007). Vitamin $\mathrm{E}$ and selenium plasma concentrations in weanling pigs under field conditions in Norwegian pig herds. Acta Veterinaria Scandinavica, 49(1), 1-9. doi: 10.1186/1751-0147-49-1.

Sutovsky, P., Kerns, K., Zigo, M., \& Zuidema, D. (2019). Boar semen improvement through sperm capacitation management, with emphasis on zinc ion homeostasis. Theriogenology, 1(137), 50-55. doi: 10.1016/ j.theriogenology.2019.05.037. 
Takahashi, M. (2012). Oxidative stress and redox regulation on in vitro development of mammalian embryos. J Reprod Dev., 58(1), 1-9. doi: 10.1262/jrd.11-138n.

Valko, M., Leibfritz, D., Moncol, J., Cronin, M.T., Mazur, M., \&Telser, J. (2007). Free radicals and antioxidants in normal physiological functions and human disease. Int J Biochem Cell Biol., 39(1). 4484. doi: 10.1016/j.biocel.2006.07.001.

Vlizlo, V. V., Fedoruk, R. S., \& Iskra, R. Ia. (2018). Biolohichna diia funktsionalnykh nanomaterialiv $u$ riznykh vydiv tvaryn. Visnyk ahrarnoi nauky, 11(788), 80-86. doi: 10.31073/agrovisnyk201811-11 (in Ukrainian).

Wu, Y., Guo, L., Liu, Z., Wei, H., Zhou, Y., Tan, J., Sun, H., Li, S., Jiang, S., \& Peng, J. (2019). Microelements in seminal and serum plasma are associated with fresh semen quality in Yorkshire boars. Theriogenology, 132(1), 88-94. doi: 10.1016/j.theriogenology.2019. 04.002 . 